\title{
LINEAR ACCELERATOR DRIVEN (LADR) AND REGENERATIVE REACTORS (LARR) FOR NUCLEAR NON-PROLIFERATION
}

Meyer Steinberg, H. Takahashi, J.R. Powell,

AND H.J.C. KOUTS
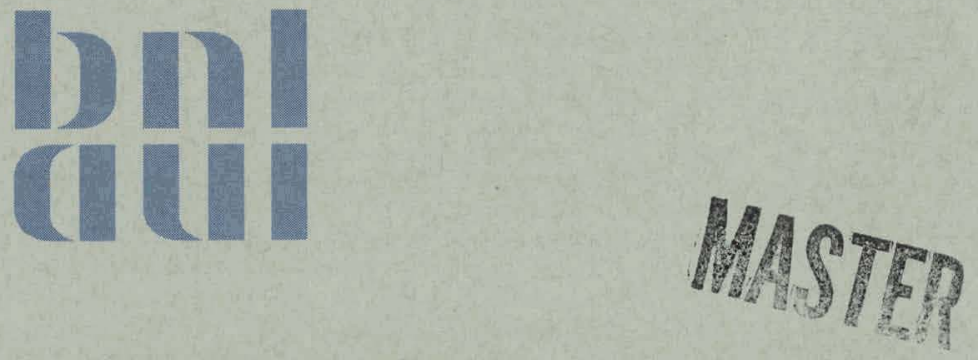

September 1977

BROOKHAVEN NATIONAL LABORATORY

ASSOCIATED UNIVERSITIES, INC. UNDER CONTRACT NO. EY-76-C-02-0016 WITH THE

UNITED STATES DEPARTMENT OF ENERGY 


\section{DISCLAIMER}

This report was prepared as an account of work sponsored by an agency of the United States Government. Neither the United States Government nor any agency Thereof, nor any of their employees, makes any warranty, express or implied, or assumes any legal liability or responsibility for the accuracy, completeness, or usefulness of any information, apparatus, product, or process disclosed, or represents that its use would not infringe privately owned rights. Reference herein to any specific commercial product, process, or service by trade name, trademark, manufacturer, or otherwise does not necessarily constitute or imply its endorsement, recommendation, or favoring by the United States Government or any agency thereof. The views and opinions of authors expressed herein do not necessarily state or reflect those of the United States Government or any agency thereof. 


\section{DISCLAIMER}

Portions of this document may be illegible in electronic image products. Images are produced from the best available original document. 


\title{
LINEAR ACCELERATOR DRIVEN (LADR) AND REGENERATIVE REACTORS (LARR) FOR NUCLEAR NON-PROLIFERATION
}

\author{
Meyer Steinberg, H. Takahashi, J.R. Powell, \\ AND H.J.C. KOUTS
}

September 1977

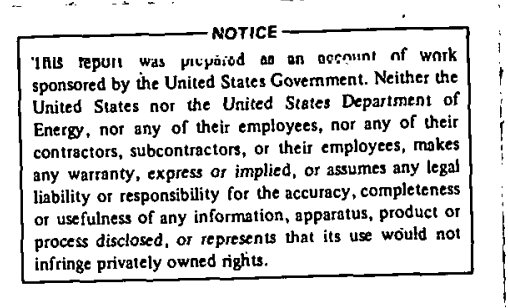

BROOKHAVEN NATIONAL LABORATORY UPTON, NEW YORK 11973 
NOT I CE

This report was prepared as an account of work sponsored by the United States Government. Neither the United States nor the United States Department of Energy (DOE), nor any of their employees, nor any of their contractors, subcontractors, or their employecs, malios any warranty, crpreso or implicd; or assumes any legal liability or responsibility for the accuracy, completeness or usefulness of any information, apparatus, product or process disclosed, or represents that its use would not infringe privately owned rights.

Printed in the United States of America

$$
\text { Available from }
$$

National Technical Information Service

U.S. Department of Commerce

5285 Port Royal Road

Springfield, VA 22161

Price: Printed Copy $\$ 4.0$, Microfiche $\$ 3.00$

November $1977 \quad 50 \quad 240$ copies 


\title{
LINEAR ACCELERATOR DRIVEN (LADR) AND REGENERATIVE REACTORS (LARR) FOR NUCLEAR NON-PROLIFERATION
}

\author{
by \\ Meyer Steinberg, H. Takahashi, J. R. Powell, and H. J. C. Kouts \\ Brookhaven National Laboratory \\ Upton, New York 11973
}

August 1977

\section{Introduction}

The Linear Accelerator Breeder (LAB) ${ }^{(1)}$ or Electronuclear Breeder (ENB) $)^{(2-4)}$ had its early origin in the MTA Project Materials Testing Accelerator) which was worked on during the early days of the Lawrence Livermore Laboratory (LLL), for the purpose of ensuring production of fissile material for weapons. $\mathrm{LAB}$ is a device which would use a powerful linear accelerator to produce an intense beam of protons or deuterons impinging on a target of a heavy element such as uranium or lead to produce spallation and cascade neutrons. These neutrons could in turn be absorbed in fertile U-238 or Th-232 to produce fissile Pu-239 or $\mathrm{U}-233$.

Interest has recently been revived in the $\mathrm{LAB}$ as an alternative mode for the production of fissile fuel ${ }^{(1,5)}$ for the nuclear power program, where it could be a backup to the Liquid Metal Fast Breeder Reactor (LMFBR) in case development of the fast breeder becomes delayed. Because of the advances in linear accelerator technology over the last 25 years, there is now considerable assurance that a high current continuous wave high energy proton machine can be built to operate reliably at a reasonable cost. 
LAB can also be considered as potentially competitive to the production of enriched U-235 in the head end of the fuel cycle since LAB would produce fissile fuel from natural fertile material. Enrichment, however, does not extend the nuclear fuel supply in conjunction with present day nuclear burner power reactors, whereas the Linear Accelerator Fuel Producer (LAFP) could extend the fuel resource.

Linear accelerators could be used to produce fissile fuel in two modes, either with fuel reprocessing or without fuel reprocessing. With fuel reprocessing, the fissile material would be separated from the target. and refabricated into a fuel element for use in a burner power reactor. Without reprocessing, the fissile material would be produced in-situ, either in a fresh fuel element or in a depleted or burned element after use in a power reactor. In the latter mode the fissile material would be increased in concentration for reuse in a power reactor. We call this system a Linear Accelerator Regenerative Reactor (LARR).

The $L \Lambda B$ can aloo be conccived of opcrating in a power production mode in which the spallation neutrons would be used to drive a subcritical assembly to produce power. We call this a Linear Accelerator Driven Reactor (T.ADR).

The Administration's recent nuclear non-prollferation policy has recommended that plans for nuclear fuel reprocessing be stopped for the time being, and that development of the Clinch River Breeder Reactor be halted. (6) A review is under way to determine the technical options avallable for reducing opportunities for proliferation of nuclear weapons capability..throughout the world. Among the options being explored are the following: 


\section{1. eliminate reprocessing}

2. IImit enrichment

3. Iimit transport of fuel

4. maintain low concentration of fissile material in power reactor fuel

5. approach a throwaway fuel cycle.

Many of the measures of this kind would also act in the direction of reducing the total energy available from uranium resources. A number of alternatives are being explored to solve this problem, including the following:

1. find additional natural uranium resources

2. reduce enrichment plant tail concentrations

3. try to use thorium as a nuclear fuel

4. try to use new fuel cycles

Both the Linear Accelerator Driven Reactor (LADR) and the Linear Accelerator Regenerative Reactor (LARR) appear to offer a high potential for extending the nuclear fuel supply while at the same time reducing the riak of proliferating weapons capability through misuse of the nuclear power fuel cycle.

Principles of the Linear Accelerator Driven Reactor (LADR)

The LADR would consist of a subcritical reactor target containing depleted uranium, natural uranium, slightly enriched uranium, or thorium, producing a net amount of energy when supplied with neutrons generated by stopping a high energy proton beam from a linear accelerator.

A critical economic parameter is the amount of electrical power needed to drive the accelerator, relative to the power output from the reactor 
target. The expression for the ratio of power output from the target to power input to the accelerator $\left(\mathrm{P}_{\mathrm{TA}}\right)$ is given in Table 1. Reasonable values have been chosen for the spallation neutron yield ( 50 neutrons per proton on a uranium target), power cycle efficiency and accelerator efficiency ( $35 \%$ and $50 \%$, respectively), and the value of neutrons per fission from uranium (3 neutrons/fast fission). Based on these assumptions, the power ratio $\left(\mathrm{P}_{\mathrm{TA}}\right)$ was calculated as a function of the multiplication factor (k). The results are given in Table 1. As an economic rule of thumb, the power consumption of the accelerator should not be more than about $20 \%$ of the , net electrical output of the target. At values of $k$ below about 0.9 the power required to be circulated back to the accelerator becomes a significant fraction of the total power output of the target reactor. For example at $k=0.8$, the power consumption of the accelerator would be $40 \%(100 / 2.5)$ of the electrical output of the target, and at $k=0.6$, the accelerator would consume about $95 \%(1 / 1.05)$ of the target reactor power. It appears that the design of the target assembly must be such as to yield a value of $k$ of 0.9 or greater.

Neutronic burnup calculations have been made for target assemblies consisting of fuel elements similar to those used in LWR's. A unit cell of zircaloy-clad $\mathrm{UO}_{2}$ elements in light water coolant was used with a volume ratio of 2 parts water to 1 part fuel. The calculated intinite multiplication factor $\left(k_{\infty}\right)$ is shown in Figure 1 , as a function of the burnup in $\mathrm{GWD} / \mathrm{ton}(1000 \mathrm{MWD} / \mathrm{ton})$. If the fuel is initially depleted $\mathrm{UO}_{2}$ (i.e., tails from enrichment plants), the calculated value of $k_{\infty}$ rises from a very low value to a peak value of a little above 0.8 , and then slowly falls to a value of about 0.7 after a burnup of over $100,000 \mathrm{MWD} / \mathrm{ton}$. At the beginning 
of a cycle, starting from all fresh fuel, there would have to be a relatively larger energy input and circulating power investment before higher values of $k_{\infty}$ are reached, and the circulating power load is reduced. However, at the peak, the circulating power would still amount to over $40 \%$ of the target power. Closer lattice spacing (lower water/fuel ratio) will increase $\mathrm{k}_{\infty}$ and improve performance somewhat.

The situation is somewhat Improved if the fraction of fissile $\mathrm{U}^{235}$ initially in the $\mathrm{U}^{238}$ increases. With natural uranium $\left(0.7 \% \mathrm{U}^{235}\right)$ the $\mathrm{k}_{\infty}$ is initially about $0 . \overline{6}$, but it still does not rise much above 0.8 on 1onger burnups, so that the circulating power would still be relatively large. Heavy water cooling or liquid metal sodium cooling would help to increase the value of $\mathrm{k}_{\infty}$ for both depleted natural uranium and enriched uranium fueled assemblies. With heavy water the $k_{\infty}$ would reach values of 0.9 or more on burnup to over $100,000 \mathrm{MWD} / \mathrm{ton}$. However, the use of heavy water would increase the departure from present day US commercial nuclear technology.

One interesting scenario whose implications are being explored is the following:

1. Fuel is initialiy burned in a conventional LWR with a conversion ratio of 0.6 , to the usual burnup of about $30,000 \mathrm{MWD} / \mathrm{ton}$.

2. The elements, which now contain about $1.8 \%$ fissile material $\left(\mathrm{Pu}^{239}\right.$ and $\left.\mathrm{U}^{235}\right)$ are placed in the reactor target of an LWR cooled LADR, and burned to a value of $k_{\infty}$ of about 0.9 . With fuel shuffing in the LADR, additional burnup by an average of $30,000 \mathrm{MWD} /$ ton would lead to burnup at an additional level of about $60,000 \mathrm{MWD} / \mathrm{t}$ on in fuel removed from the LADR. This would treble the energy avallable from uranium, as compared with the throwaway LWR cycle alone. 
Additional neutronic and design calculations are being conducted on the LADR approach. The concept seems to satisfy the objectives stated above of restraining proliferation and stretching the fuel reserves.

The Linear Accelerator Regenerative Reactor (LARR) Concepts

The LARR would be fundamentally a fuel producer, as opposed to the LADR which would be primarily a power producer. The LARR would be used to irradiate fuel to a level of reactivity so that 1t could produce the fuel in-situ for a normal power reactor. The LARR could be used to irradiate depleted, natural, or enriched uranium fuel, as well as thorium fuel.

Table 3 gives the basic equations for the rate of fuel production in the target and the power which can be supported with this fuel. The fuel production is a direct function of the proton current and neutron yield per GeV proton, and an indirect function of the conversion ratios and multiplication factors. For the limiting case of starting with unenriched $\mathrm{U}^{238}$, the relative capacity of power reactors which can be supported by the accelerator target reactor reduces to mainly being a strong function of the power reactor conversion ratio. For a conventional LWR, the conversion ratio is 0.6 and therefore an accelerator capacity of about $22 \%$ of the LWR capacity wnuld be required to regenerate the fuel. It is desirable to produce a hard neutron spectrum in the regenerator to maximize fuel production and therefore either light or heavy water steam coolant in the regenerator is preferred. If the regenerator supplies fuel to a heavy water cooled power reactor, such as the Canadian pressure tube CANDU reactors, the conversion ratio can be increased and the regenerator can be made smaller. 
The LARR could be sited in an energy park, supplying regenerated fuel to a number of reactors at the same site. This would reduce the opportunity fortheft of the nuclear material, which would never be transported off site and would be extremely radioactive in all cases where it contained appreciable amounts of fissile material.

IV. Technical Problems of LADRs and LARRs

\section{1) Window Problem}

The interface between the linear accelerator and the LADR or the LARR would pose difficult problems. The accelerator beam is formed and accelerated in a vacuum and must then be injected into a target assembly which if water cooled operates under higher pressure. Two types of window can be considered, (1) a thin water-cooled shell which would probably require frequent replacement due to radiation damage and (2) the heavy calandria type pressure tubes which are smaller in diameter and wall thicknesses and would contain smaller unit assemblies of nuclear fuel.

\section{2) Target Problem}

The problems of a thin window would be relieved if a liquid metal coolant with high boiling point such as lead is used. However, there are two drawbacks to this. First, a suitable container material for the lead would be required, which would transmit large amounts of lieutrons. Secondly, the yield of neutrons from high energy proton bombardment of a heavy liquid metal target is about half that from beam interaction with uranium, because fast fission of the uranium by high energy neutrons amplifies the yield. 


\section{3) Materials Problem}

Problems of radiation damage to cladding are much more important with the LADR and LARR, because the concept is based on obtaining much higher burnups with high energy protons and neutrons than with conventional lower energy neutrons in a power reactor. In case of zircaloy clad- $\mathrm{UO}_{2}$, thicker cladding or annealing between the LWR and the LADR may be advantageous. It is interesting to note that some LWR fuel elements have been burned to $60,000 \mathrm{MWD} /$ ton and that the stainless steel clad elements of the CRBR were being designed for $150,000 \mathrm{MWD} /$ ton. 


\section{References}

1. M. Steinberg, et al. "Linear Accelerator Breeder (LAB)", BNL 50592 (November, 1976).

2. F. R. Mynatt, et al. "Preliminary Report on the Promise of Accelerator Breeding and Convertor Reactor Symbiosis", (ABACS) as an Alternative Energy System", ORNL 5750, (February 1977).

3. C. M. Van Atta et al. "The Electronuclear Conversion of Fertilizer Fissile Material, UCRL 52144 (October 1976).

4. J. S. Fraser et al. "The Role of Electrically Produced Neutrons in Nuclear Power Generation" AECL 4088, Chalk River, Canada (October 1973).

5. H. J. C. Kouts, Chairman, "Information Meeting on Linear Accelerator Breeders, held at BNL on January 18 and 19, 1977', ERDA Conf. Report 770107 (to be published).

6. Jimmy Carter, Presidental Policy Statement (April 7, 1977), 
Table 1

\section{DRIVEN REACTOR SYSTEM}

$\mathrm{P}_{\mathrm{TA}}=$ Power output from target/power input to accelerator

$$
P_{T A}=E_{P} E_{A} \quad\left[\left(Y \times \frac{k}{v} \times \frac{1}{1-k}\right) 0.2+1\right]
$$

$E_{P}=$ efficiency of power cycle $\sim 0.35$

$\mathrm{E}_{\mathrm{A}}=$ efficiency of accelerator $\sim 0.50$

$\mathbf{Y} \equiv$ spallátion neutron yield from target per 1. GeV proton ? 50

$v=$ number of neutrons/fission $\sim 3.0$

k multiplication factor

$\begin{array}{ll}\underline{k} & \frac{P_{\mathrm{TA}}}{0.6} \\ 0.7 & 1.05 \\ 0.8 & 1.54 \\ 0.9 & 2.51 \\ 0.95 & 5.43\end{array}$


Table 2

\section{LINEAR ACCELERATOR REGENERATIVE REACTOR}

$F=$ production rate of fissile fuel $=\mathrm{Kgm} / \mathrm{yr}$

$$
F=0.0786 \text { IY }\left(\frac{C_{T}-1}{C_{T}+1}\right)\left(\frac{1}{1-k_{T}}\right)
$$

$I=11$ near accelerator proton current

$Y=$ spallation neutron yield per $\mathrm{GeV}$ proton

$$
P_{T A}=E_{p} E_{a}\left[Y \times\left(\frac{C_{T}-1}{C_{T}+1}\right)\left(\frac{1}{1-k_{T}}\right)\left(\frac{1}{1-C_{P}}\right) \times 0.2+1\right]
$$

$P_{\mathrm{TA}}=\frac{\text { Total power output from power reactors }}{\text { to power input to accelerator }}$

$E_{p}=$ efficiency of power cycle

$E_{a}=$ efficiency of accelerator

$\mathrm{C}_{\mathrm{T}}^{\mathrm{a}}=$ conversion ratio for target reactor

$\mathrm{C}_{\mathrm{P}}=$ conversion ratio for power reactor

$k_{T}=$ multiplication factor for target reactor

For the special case of starting with unenriched $U^{238}$ in the regenerator

$$
\mathrm{C}_{\mathrm{T}} \rightarrow \infty \text { and } \mathrm{k}_{\mathrm{T}} \rightarrow 0
$$

so that $F=0.0786$ I $Y$

Thus for $I=300 \mathrm{ma}$ and $Y=50$

$$
F=1180 \mathrm{Kgm} / \mathrm{yr}
$$

and $P_{T A}=E_{p} E_{0}\left[X \times \frac{1}{1-E_{P}} \times 0.2+1\right]$

when $E_{p}=0.35, E_{a}=0.50$ and $Y=50$

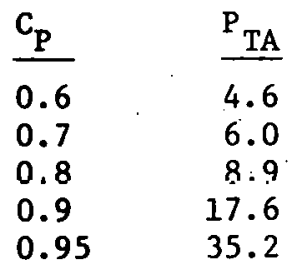




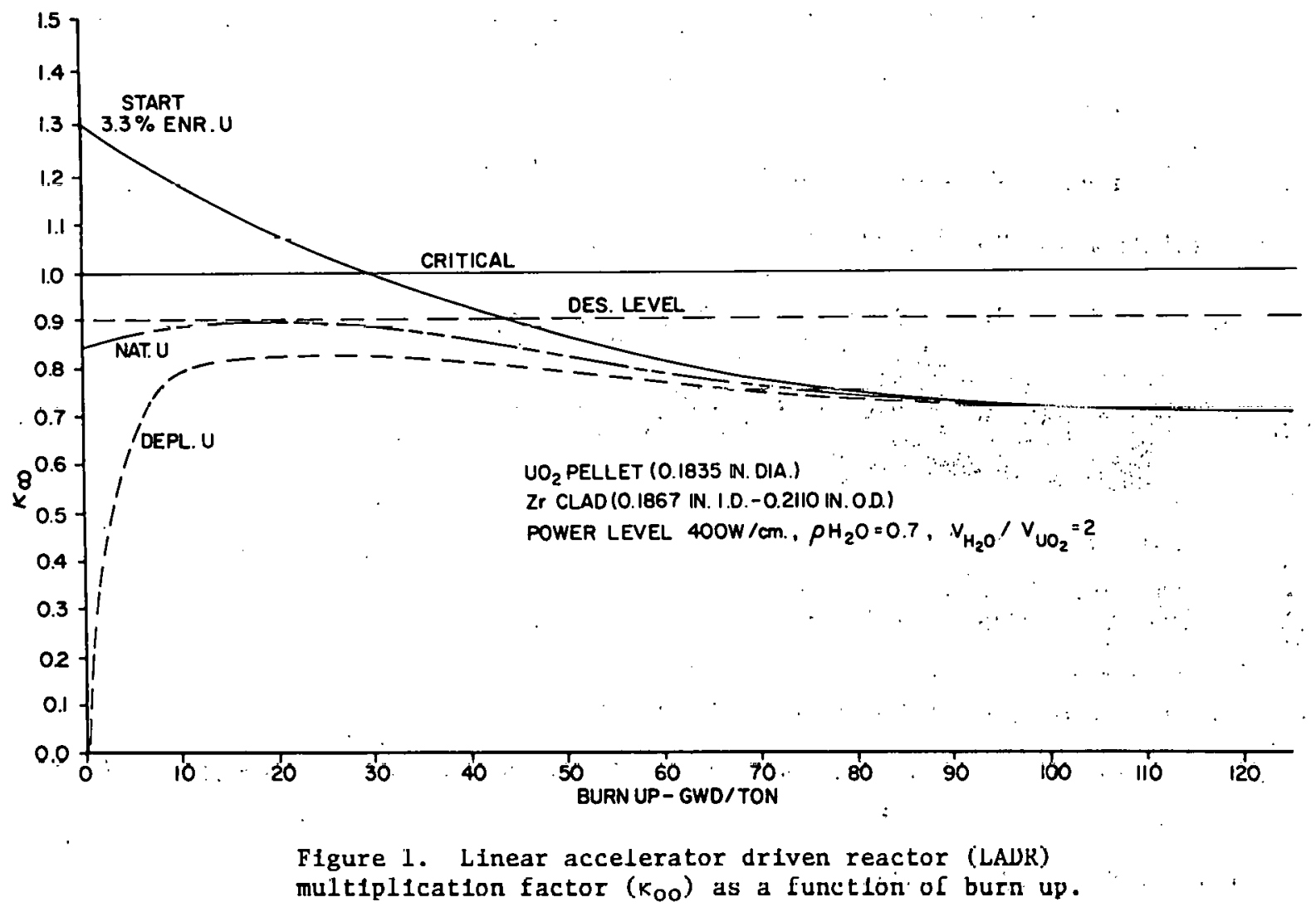

